\title{
Breast Cancer Paradox: High Curability versus High Mortality from a Gender Perspective
}

\author{
Maria Gabriela Ribeiro Portella1, Virginia Dresch ${ }^{1,2 *}{ }^{*}$, Maria Martha de Luna Freire ${ }^{3}$, \\ Ingrid Moraes de Siqueira ${ }^{1}$
}

\author{
${ }^{1}$ Research Group Psychological Assessment Laboratory (CNPq), Niterói-RJ, Brazil \\ ${ }^{2}$ Department of Psychology, Universidade Federal Fluminense (UFF), Niterói-RJ, Brazil \\ ${ }^{3}$ Department of Planning Health, Universidade Federal Fluminense (UFF), Niterói-RJ, Brazil \\ Email: *virginiadresch@id.uff.br
}

How to cite this paper: Portella, M.G.R. Dresch, V., de Luna Freire, M.M. and de Siqueira, I.M. (2019) Breast Cancer Paradox: High Curability versus High Mortality from a Gender Perspective. Health, 11, 1257-1271. https://doi.org/10.4236/health.2019.1110097

Received: September 4, 2019

Accepted: October 6, 2019

Published: October 9, 2019

Copyright (c) 2019 by author(s) and Scientific Research Publishing Inc. This work is licensed under the Creative Commons Attribution International License (CC BY 4.0).

http://creativecommons.org/licenses/by/4.0/

cc) (i) Open Access

\begin{abstract}
Despite being considered a potentially curable disease, breast cancer is the most frequent cause of cancer death in women worldwide, establishing the following paradox: high curability versus high mortality. Among the conditions conducive to this situation, such as difficult access to diagnosis and treatment and social support by the State, there is the need to discuss the impact of women's caregiving, the backbone of the female gender role, on self-care in health. Gender has a powerful effect on determining health status: it may limit different rates of exposure to certain risks, different patterns in the quest for treatment or differential impacts of the social and economic determinants of health. The study shows the results of a qualitative methodology with nine women aged 48 to 74 years with varying levels of schooling and socioeconomic status, who had breast cancer at some stage of adult life and who regularly attend a nongovernmental organization (NGO) to support women with breast cancer, in the city of Niterói (Rio de Janeiro, Brazil). The participants' discourses evidenced the idea of the primacy of the caregiving, the idealized image of the warrior woman and their self-neglect and State's care as elements of the potential impact on the choices of these women concerning self-care, and consequently in their experiences of illness.
\end{abstract}

\section{Keywords}

Breast Cancer, Gender, Women's Health

\section{Introduction}

This work begins with the "breast cancer paradox": high curability versus high mortality. Breast cancer is a potentially curable disease if detected early. Howev- 
er, it is currently the most frequent cause of cancer death in women, accounting for $25 \%$ of all cancer cases worldwide [1] and $28.1 \%$ of cancer cases in Brazil [2].

Access to breast cancer diagnosis and treatment is inadequate in poorer countries. In resource-poor regions (including Brazil) with weak and fragmented health systems, breast cancer contributes to the preservation of the poverty cycle [[3], p. 847], since:

1) Most women who die of breast cancer in the world live in low- and middle-income countries. This situation is a widely preventable tragedy for hundreds of thousands of women and their families.

2) Most women who develop breast or cervical cancer in a high-income country will survive. The opposite is true for women in most low-income and many middle-income countries.

3) The incidence of breast cancer is expected to increase rapidly with increased human development.

4) Global efforts, especially in recent years, have led to substantial improvements in maternal health outcomes. Similar efforts are urgently required to address breast and cervical cancer, which take the lives of three times more women each year than pregnancy complications (e.g., maternal mortality).

In Brazil, users face many obstacles to access the Family Health Strategy (ESF), a care model adopted in the country since the 1990s to consolidate the principles of the Unified Health System (SUS) based on primary care. Shimizu, Trindade, Mesquita, and Ramos [4] point out a lack of access, especially concerning poor service efficiency; since it is difficult to schedule visits, the waiting time for scheduled visits is very high, and laboratory tests results are lengthy [5].

Delayed diagnosis and onset of treatment is a complicating factor in breast cancer treatment, since a tumor growth model has predicted that, on average, a tumor of $2 \mathrm{~cm}$ (the average size when a tumor first becomes clinically palpable) takes 12 months to double in size, and 24 months to reach $6 \mathrm{~cm}$ in size [6]. The larger the tumor size, the more advanced the disease staging. The advanced stage at diagnosis is difficult and costly to treat and is associated with increased morbidity and low survival in high-income countries [7] [8] and in Brazil [9]. Also, staging will define the degree of potential treatment invasion: from chemotherapy/radiotherapy alone to radical mastectomy with axillary lymph node emptying and the presence of metastasis [10]. Therefore, the earlier cancer is detected and treated, the more likely it is to cure and the less impact on the quality of life of women and their families. In contrast, delayed diagnosis or search for care has resulted in up to $70 \%$ of women diagnosed with breast cancer undergoing mutilating surgery [11].

The clinical and mammographic screenings were introduced in Brazil in 2004 for women aged 50 years and over. However, coverage is still insufficient. Barreto, Mendes, and Thuler [12] revealed that only $68.4 \%$ of the female population is covered by breast cancer screening actions in southern Paraíba. Dos-Santos-Silva et al. [13] found that the prevalence of late-stage breast cancer at diagnosis 
remained high throughout the 2001-2014 period, at approximately $40 \%$, inversely associated with educational level, and was higher for Brazilian women who self-declared as black and brown compared to white.

Thus, our second point is about relationships between sex, gender, and health [14]. Sex has a substantial impact on determining the health status: in fact, it may establish the differential propensity to certain states of health or illness, different risk factors, or treatment needs. Similarly, gender also exercises a powerful effect on determining the health status: it may limit different rates of exposure to certain risks, different patterns in the search for treatment or different impacts of the social and economic determinants of health.

The concepts of gender developed over time begin with the idea of gender differentiation and the way societies are unevenly structured to understand the indivisibility of micro and macro relationships that will mark gender-based inequalities. Barbosa [15] presents the concept of gender as an alternative to critically understand the reduced ways of living linked to social norms, a possibility to articulate theory and practice, highlighting the relevance of activities performed by women in the domestic sphere that affect their social reproduction, permeating life aspects and thus naturalizing them.

The in-depth analysis of the processes involved in the social structuring and the process of women subjectivation was fundamental for the development of the gender category and its conceptualization over time. Gender clears the barrier of the hierarchical condition of the social division between genders, and is strategic to overcoming the inequalities experienced by women regarding their naturalized condition of caregivers, the backbone of the female gender role. Women tend to prioritize caregiving and find it very difficult to put themselves in the place of those who receive care [16], which may contribute to delaying or not seeking health care.

The lack of an integrated social protection system further burdens women in their caregiving role. In Brazil, although isolated social protection actions are in place, there is no integrated system to assist families in the care of children, people with disabilities and the elderly, as in other countries such as Spain and Uruguay. Spain established through Law 39/2006 the Sistema para la Autonomía y Atención a la Dependencia (SAAD), which provides for the expansion of services in daycare centers, nursing homes, day hospitals, etc., besides the possibility of remunerating a non-professional caregiver (mainly family mothers) who care for people in a dependent situation (children, the elderly or disabled) at home [17]. In Uruguay, the Sistema Nacional Integrado de Cuidados (SNIC) was approved in 2011, and provides for the expansion of services to daycare centers, nursing homes, day hospitals, etc., as well as the possibility of hiring a state-paid personal assistant to collaborate in the household chores of families providing their care to people (children, older adults and relatives with disabilities) with severe dependence [18].

Among the changes triggered in the illness process, the impacts on caregiving 
contribute to changes in the emotional economy of women established throughout history, configured, in particular, by valuing the needs of others and making them responsible for their care [19]. While temporary in the position of caregiver or care receiver, change can be dubious. On the one hand, women may feel safe and welcomed by family or friends; on the other, they cease to hold a place that has always been theirs, generating a feeling of "uselessness" and the need to accept being "replaced" by someone supposedly less capable at that time [16].

As a result, it is necessary to identify/recognize the potential influence of gender assumptions, in particular, the almost exclusive attribution of the caregiving role to women, in accessing and adhering to the diagnosis and treatment of breast cancer, and to propose measures to address this issue. As a contribution to the reflection on this theme, this study was conducted through a qualitative methodology and aimed to know the perceptions of women who had breast cancer about their illness and process of choosing care from a gender perspective, especially the role of caregiver.

\section{Methods}

\subsection{Participants}

Nine women who had breast cancer at some stage of adult life and regularly attend a nongovernmental organization (NGO) to support women with breast cancer, from the city of Niterói (Rio de Janeiro, Brazil) were invited and accepted to participate in the study. These women were aged 48 to 74 years, with varying levels of schooling and socioeconomic status.

\subsection{Instruments and Procedure}

Data collection included interviews guided by an invisible script and conducted from the facts narrated by the respondents, aiming to reconstruct the life history of these women from the diagnosis, with emphasis on gender crossings concerning the role of care. Data were collected from a non-governmental organization (NGO) supporting women with breast cancer. The interviews were held from June 2018 to August 2018, preceded by the explanation of the research and signing of the informed consent term.

The interviews were recorded, with an average duration of 40 (forty) minutes and their content transcribed. The recordings are kept under the responsibility of the researchers.

The methodological approach used with the participants was the Topical Life Story [20] [21] with emphasis on the stage of life after the diagnosis of breast cancer, which admits that this technique favors the view of those who experience the studied subject, revealing the facts from the perspective of those who experience them and the relationships they establish with events. This choice was given by the History of Life to admit that this technique privileges the view of those who experience the subject studied, allowing to know the facts from the perspective of those who experience them and the relationships they establish 
with events. The therapeutic itineraries guided the interview [22].

\subsection{Data Analysis}

The collected data were submitted to thematic content analysis, which aims to identify meaning cores underlying a set of references and values in the subjects' discourse [23]. Using this technique, we sought to build categories of analysis from the organization of meaning cores. Thus, the following steps were followed after transcribing the interviews: 1) floating reading of the material; 2) identification of statements' regularities; 3 ) organization from common meaning cores: 4) construction of analysis categories; and 5) the analysis itself.

Content analysis works by breaking apart text into units into categories according to analogous groupings. Among the different possibilities of categorization, the investigation of the themes, or thematic analysis, is quick and effective on the condition that it applies to direct (manifest meanings) and simple discourses [24].

\subsection{Ethical Aspects}

The project was approved by the Research Ethics Committee of the Universidade Federal Fluminense under reference number 2.653.743.

\section{Results}

Personal characteristics, life histories and ways of dealing with the disease brought to light unique experiences and guided the description and identification of respondents with flower names, relating them to the meanings attributed to them in popular culture. Table 1 describes the main characteristics of the participants.

Thus, the itineraries reported by the participants allowed us to identify how women diagnosed with breast cancer face the care norms historically established by gender norms, and establish relationships of self-care and caregiving at different times of life and treatment stages. On the other hand, the articulation of

Table 1. Description of participants.

\begin{tabular}{cccc}
\hline Fictitious name & Age & Labor activity & Age at diagnosis \\
\hline Gérbera & 48 years & Housewife and craftswoman & 45 years \\
Girassol & 60 years & Retired administrative assistant & 28 years \\
Helicônia & 71 years & Retired banker, but working & 49 years \\
Lírio & 55 years & Retired kitchen porter & 41 years \\
Amarílis & 57 years & Sales promoter & 37 years \\
Dália & 64 years & Housewife & 53 years \\
Flor do campo & 74 years & Housewife & 64 years \\
Azaleia & 71 years & Housewife & 61 years \\
Lotus & 70 years & Housewife & 63 years
\end{tabular}


their reports facilitates the understanding of social phenomena that encompass the way women with breast cancer experience their illness, allowing us to grasp the aspects that collectivize in their discourses.

The data obtained allowed us to establish three categories of analysis, namely: a) primacy of caregiving; b) imperative of the warrior woman; and c) self-neglect and State "care".

\section{1) Primacy of caregiving}

This category expresses the concept of priority and centrality of caregiving, contained in the discourse of women who, even after the diagnosis of severe disease and during their treatment, maintain their condition of caregiver even if they are located, at a given moment, at the other end of care. It reveals the way women give up their self-care, including putting themselves at risk, prioritizing the care they idealize should be provided by them to figures historically shown as the object of their care (children, husbands, and dependent elderly). By highlighting this concept, the participants' discourse shows their open submission to gender norms that establish caregiving, mainly linked to the maternal condition.

(...) I had my mother. She had a stroke, and I took care of her, I gave up my love life to take care of her and took care of her for 15 years. In those 15 years, she had seven strokes, and, in the meantime, I had breast cancer. Well, my concern when I received the news was just her, because she was cute. When the doctor told me, "Lotus, you have aggressive cancer, and we have to operate as soon as possible", I said: "Doctor, what about my mother? How am I going to talk to my mother?" (Lotus, 70 years old).

(...) However, I had to take care of my daughter; you know, when someone gets completely upset, not knowing what to do, it's challenging. It was difficult for me because I still had to stay at her house (Azaleia, 71 years old). (...) My son had already scheduled his trip just after the carnival, when I was going to his house. I said: "I can't tell him; I still don't have a written diagnosis. She referred me, but I still don't have a diagnosis, he won't travel... I'm sure I know my son" (Flor do Campo, 74 years old).

\section{2) Imperative of the warrior woman}

This category encompasses the discourses of women who put themselves in a position of some privilege for having endured sufferings that are not socially recognized, as if not overcoming them were a sign of weakness or loss of identity. Although they are experiencing some social or cultural injustice, they are called upon by society and themselves to "handle" certain circumstances, often becoming an example of overcoming adversity-although it could have been avoided, causing less damage to them.

Because the day I left the hospital, I came home starving. Then my husband's niece had stayed at my house. I had left, and I came back home. There was nothing to eat, and I turned to him and said, "Go to the market, buy carrot, chayote, potato, pasta, meat, and I'll make us some soup". "So 
you can't go," I said, "but I'll do it, I'm hungry." I went to the stove, I made the soup, I did everything, they came, and they also ate the soup I made (Girassol, 60 years old).

I didn't leave work. The doctors didn't remove me from work... I only left when I had the surgery. I left like this: when I had chemotherapy, I stayed at home, and after two days, I was back at work. (...) I have always enjoyed living life, but after cancer, I started to live much more intensely because I had this surgery. I felt like a warrior. So much so that I am a living example for my work to this day (Amarílis, 57 years old).

Then I had chemotherapy, eight sessions, but I didn't need to do radiotherapy. I went back to work after a fortnight of surgery. (...) I had to continue my life. I had two teenage children. It was no use staying indoors crying because I had cancer. It wasn't going to lead me anywhere. And I made it, thanks to my bosses, they were all very supportive. I went every day, and they said "just come in anytime you want, leave anytime you want", and so it was. I had eight chemotherapy sessions. I left chemo and went to work (Helicônia, 71 years old).

But then I came to Niterói, and I didn't know anyone. I started all over again on my own. My husband died; I had to restart my life. Then, when I was sick, I had to restart my life again coming to Niterói (Azaleia, 71 years old).

In these passages, the lack of protection due to the absence of a care network, especially the family, or the condition of social precariousness, appears as an overcoming opportunity. These women do not seem to resent their feelings of helplessness, but to accept or even feel proud to be made warriors. The two examples cited show how they relate to these limitations, placing them as an opportunity to show their strength even in times of fragility. That is, admitting as the only possibility of re-signifying the condition of the positive overcoming of the disease.

\section{3) Self-neglect and State "care"}

The category describes the way women diagnosed with breast cancer deal with the vulnerable social protection devices provided by the State because of their social role as caregivers. It exposes the inexistent or insufficient state social protection devices that enable women to take care of themselves, proving to be limiting the success of early screening and treatment.

That same year, 2008 (year of diagnosis), when she was born, the daycare center was on a recess. And the caregiver comes in again. Who is left? Grandma. (...) And she was baby. So since she was a baby, she was a skinny, tiny baby, not very agitated or anything, I thought that was fine. I was in that period of the last fortnight of December. I started feeling very severe pain on the side in January, the surgery side. And I knew something was wrong, so I went to the INCA. So I was reprimanded by the doctor... (Dália, 64 years old).

(...) because at that time I could even get a pass, at the time of Rosinha and 
Garotinho ${ }^{1}$. They suspended everything... I didn't even get a pass; I had to pay for a ticket (Lírio, 55 years old).

It is necessary to highlight how the fragility of the State's social protection mechanisms leads to self-care relativization, contributing to it being seen as women "carelessness". The lack of social protection devices that can support women becomes a new element that adds to the impacts that will be faced during treatment. Concerning social protection, not only must access to health services be planned, but also conditions for women to remain adherent to treatment after diagnosis.

\section{Discussion}

The statements of women participating in the research proved to be privileged empirical material, especially to understand how the establishment of gender norms for women is a guide for caregiving and being cared for. It also explains how the presence or absence of formal or informal support contributes to the way women describe their experiences and the possible impacts on the disease process.

The categories constructed from the respondents' discourse revealed how women who were diagnosed with breast cancer made their choices for care, allowing us to understand the thread that leads this decision-making to care concerning their caregiving role. The realization of a naturalized idea of care linked to women was confirmed as the primary normative grounding what is expected for their gendered role.

Such gender norms are not detached from long-term historical processes. The ideal of the woman caregiver was established together with the construction of the Nation-State. Donzelot [25] points to the strengthening of family feeling in the eighteenth century and shows how, in the old French regime, women were summoned to assume the role of ensuring that the house was a home and exercise care to maintain offspring. Thus, she would be responsible for the reproductive role while man provided for productive needs. Care task naturalization has been consolidated through an ideological political process that has spanned the centuries.

Maternal care as an expression of civility has been progressively naturalized as the feminine essence itself [26]. This policy contributed to men being less called upon to exercise care activities, thus ensuring what Tronto [27] conceptualizes as "protected irresponsibility". The maternalist ideas that dominated the western world in the first decades of the twentieth century reinforced the linkage of female identity to care practices and were also incorporated into the claims of various currents of feminist movements of the so-called first wave [28]. If in that period it resulted in tangible benefits for women, maternalism was later revised.

The notion of female oppression, especially by the exercise of caregiving tasks, gained relevance in feminist studies of the 1960s, based on the finding that biological sexual differences corroborated increasing social inequities, particularly 
the work performed by men and women [29]. The concept of gender emerges as an attempt to make it clear that sexual differences do not characterize relationships but instead how they are interpreted and valued socially.

By highlighting the historical constitution and naturalization of the concept of compulsory care by the ideological political bias, the discussion outlined here is not intended to deprive women of the way they identify themselves in the world through their caregiving role. However, by discussing these factors as they are presented as the main results of the research, we seek to reflect on the interference of this condition in the option of receiving care in the case of a disease that endangers the lives of these women.

The myth of maternal love pointed out by Badinter [26] seems to be confirmed when we find that women remain in their caregiving condition even when requiring care. This social role guides the relationships they establish between the experience of illness and the exercise of care. The primacy of caregiving is evident in the statements of the respondents. The reports indicate that they unfold even under conditions of unprotection and neglect to fulfill their supposed obligations and duties.

Also, following the process of naturalized maternal love, men cease to be responsible as care producers to assume the fixed position of recipients, or they become temporary reproducers of care when several contingencies lead them to perform these tasks, usually previously managed or planned by women [30]. Women with breast cancer appeared weak in many excerpts of the research statements, but they maintained the role of care organization, although they delegated its implementation to substitutes, possibly men, with consequences for self-care.

Concerning health, women are held accountable for care from conception, pregnancy, and maintenance of family life. Because it is directly linked to the concept of the exercise of love, the work performed by women throughout family history is diluted in what is prescribed and expected for women as maintainers of private life [31]. When they need health care, the gap in the participants' discourse is visible, not only due to the lack of protection they experience in the face of the insufficient care provided by health systems but also due to the unequal condition they face when they become ill.

Consistent with the idea of binary opposition of social roles, in the name of performing their caregiving role, many women give up their self-care, even when the indications and needs are noticeable. Excerpts from the discourses highlighted during the analysis show how the prioritization of the other can be placed as normative to the point of becoming an imperative of care, even when they need to be taken care of.

The naturalization of conceptions and the conformation of these gender imperatives shape how these women can re-signify their life histories in the face of an aggressive disease that causes pain and suffering. However, in many statements, the hardships experienced are transformed into stories of overcoming to 
reaffirm the condition of "power" that women caregivers believe they hold in the face of the insufficient support they receive.

It is worth reiterating that, even appearing as a disease with good prognosis, when discovered early, breast cancer is still the leading cause of cancer death in the female population. Highlighting this information only by addressing the biological factors that make up the etiology of the disease would be a way to reduce and neglect the social aspects that corroborate it to remain responsible for the high incidence and mortality rates.

The account of the interviewed women can bring to light other possible explanations for this phenomenon. Assuming that only lack of access to preventive health services would be responsible for such inequity can be a way to mask the underlying gender crossings, and become a limiting factor to change these numbers.

The paradox that emerges in this circumstance is reaffirmed in the statement of women who had their complaints little valued or even left their lives in the background to prioritize caregiving tasks. The imperative condition of caregiver omits to women two different perspectives pointed out by Tronto [27]: the first one is linked to the idea that every human being needs care at some point in his or her life, due to the inability to do so or the option not to do so; the second is related to the notion that everyone who cares also becomes vulnerable to care.

Relating these two postulations from the results found allows us to infer that many women are resistant to placing themselves in the position of the target of care, because the creation of duality caregiver/care recipient turns out to be exclusionary, as if the positions were cast in a rigid, static, inflexible, unchanging model. This condition fixedly occupied by women as caregivers prevents them from slipping into the position of being cared for, making room for a situation of vulnerability.

Women's discourse reflects this process: they choose to continue to perform their duties or to find someone they think can do so in their absence even if they need care. The change from this position held by women is not only related to a way of social production. From its naturalization, the prioritization of caregiving is shown as a mode of subjectivation, a purely feminine condition.

Acting in this sphere, believing that it is only a social change would be a strategy doomed to failure, as the caregiving role is a point of ambivalence for theories linked to the idea of female oppression. Understanding it as some oppression by its naturalization, the feminist discourse criticizes it for being a way of assigning to women this role as sole responsibility. However, this condition has also assured women for a few centuries their status as a social representative of something that they alone could exercise, highlighting its importance for the development of society, as a factor that mixes accommodation and resistance.

In the discourse of the research participants, the diagnosis of breast cancer emerges as a turning point, where they could reflect on how they have been experiencing their lives according to others. Most of the women interviewed refer 
to the diagnosis as a way of releasing tasks that were previously perceived as fundamental to their identification while living. This finding is directly related to what Kergoat [32] calls the process of "legitimation" where living is mixed with the performance of sexual "social roles", in which caregiving is reduced to a naturalistic ideology, justifying the setting of tasks as female or male.

As already stated, performing housework is recognized as one of the main tasks in women's care roles. Culturally, care work is regarded as "a work of love" [27]; its naturalization occurred through the ideal of maternal and marital duty. Thus, undervalued by their little social representativeness linked to the productive sphere, the implementation and mental burden of their organization, they appear to women as an invisible condition.

Besides the characteristics highlighted by the deponents concerning the change in posture regarding the diagnosis and care tasks, another perspective is consonant in women's discourse: the notion of caregiving precedes the other forms of care, although inequalities are performed to that effect. By dedicating themselves to the task of care, replacing the caregiver's temporary absence, other women show their sense of obligation to ensure that the task is performed, even if not by them.

In general, the research participants report that they sought in the figure of other women the possibility of meeting the need of those who are the target of their care. Although their statements identify the presence of men (husbands) temporarily performing the role of care, their performance, in general, is linked to the financial maintenance of the family, while the place of caregiver, in the domestic sphere, is held by another woman (mother, mother in law, daughter...). This condition of care work efficiency linked to the female universe contributes to maintaining the cycle of care of a vulnerable individual as a condition of vulnerability.

The recognition of the condition of a caregiver as an individual assignment appears as an overload for those who assume it. The lack of social apparatuses in Brazil that support those who require care reaffirms the need to delegate care to another woman. Thus, the consideration of care as a condition of collective right is shown as a way to have a shared division of this mandate, not only based on gender norms.

However, the notion of frailty, when it comes to breast cancer, is brought by women as an opportunity to express their strength. Not infrequently, during the interviews, the word "warrior" appeared in the statements. By using this expression, they sought to refer to the way to cope with situations of their precarious existence through the disease or the need to overcome impasses brought about by the consequences of treatment (mastectomy, hair loss), as a possibility to become examples of overcoming.

By bringing to light the characterization of the fight against cancer as a war that is waged against the disease, women emerge as surviving bodies, thus being a reason for example and pride, as they were called to overcome the ills in the 
name of appearing as an "overcoming model" for other women who may come across the same circumstances. After the diagnosis of breast cancer, although socially and emotionally affected by these marks, the respondents were often available to serve as an overcoming benchmark for other women.

In other words, the care that women who have overcome a severe disease with such relevant socio-cultural characteristics seek to provide when they appear to other women as "warriors" after treatment, keeps the female figure tied to the notion of "nursing mother". We should recall that the conceptions linked to the figure of women are always embedded in an altruistic view, with their economy of care geared to the other [19].

By highlighting such perspectives, this research does not intend to deprive women of their achievements in overcoming breast cancer. On the contrary, it recognizes that its overcoming is a reason of merit for these women. Even in the face of multiple adversities, whether seeking care in the health network or their unprotectedness due to the fragility of limiting processes that disregard the possibility of women being cared for, they try to re-signify their illness despite the limitations that historically traverse gender relationships.

\section{Limitations and Future Prospects}

This study is not intended to cover every possible care situation or provide simplistic solutions to address the paradox of high curability versus high mortality when it comes to breast cancer. However, it sought to point out possible contributory elements and realms for this breakdown to continue happening and producing "victims" of its naturalization.

Also, this paper does not intend to exhaust the theme addressed. By highlighting the hypotheses that women have different care positions and their way of producing their self-care is interfered by gender crossings, it does not seek to limit or remove women from this position. On the contrary, it seeks to contribute to the reflection of the impact of these crossings on falling ill and the need for structuring programs and policies that can address this realm.

The relevance of investigations on the perceptions of health professionals regarding the impact of social determinations, particularly gender, and more specifically the imperatives of care in self-care and adherence to screening, diagnosis, and treatment of women with cancer are also pointed out. Thus, it is worth mentioning the essential role of Permanent Health Education actions for the qualification of care and contribution to the reduction of health inequalities in Brazilian society.

Finally, this analysis highlights the need for further health studies with a gender perspective, where the impacts of women's caregiving role on the way they experience their illness can be investigated. This note not only refers to the experience of falling ill but also indicates the importance of their knowledge regarding the social and economic impact of women's illness, which is an essential tool for the strengthening and creation of the State's protection and care strategies. 


\section{Acknowledgements}

This work was carried out with the support of the Coordination for the Improvement of Higher Education Personnel, Brazil (CAPES), Financing Code 001, and of the Institutional Program of Scientific Initiation Scholarships (PIBIC) of the Fluminense Federal University (UFF), Notice 2017-2018, which is the result of a master's dissertation. We are also grateful to the Non-Governmental Organization (NGO) where the study was conducted, for their warm reception, and the women who participated in this study, for their valuable contributions.

\section{Conflicts of Interest}

The authors declare no conflicts of interest regarding the publication of this paper.

\section{References}

[1] International Agency for Research on Cancer (2017) GLOBOCAN 2012: Estimated Cancer Incidence, Mortality and Prevalence Worldwide in 2012. http://globocan.iarc.fr/Default.aspx

[2] Ministério da Saúde (2017) Políticas de Atenção Oncológica, 2017. http://portalarquivos2.saude.gov.br/images/pdf/2017/maio/16/13.Politicas-de-Aten cao-Oncologica.pdf

[3] Ginsburg, O., Bray, F., Coleman, M.P., Vanderpuye, V., Eniu, A., Kotha, R.S., Sarker, M., Huong, T.T., Allemani, C., Dvaladze, A., Gralow, J., Yeates, K., Taylor, C., Oomman, N., Krishnan, S., Sullivan, R., Kombe, D., Blas, M.M., Parham, G. Kassami, N. and Conteh, L. (2017) The Global Burden of Women's Cancers: A Grand Challenge in Global Health. The Lancet, 389, 847-860. https://doi.org/10.1016/S0140-6736(16)31392-7

[4] Shimizu, H.E., Trindade, J.S., Mesquita, M.S. and Ramos, M.C. (2018) Avaliação do Índice de Responsividade da Estratégia de Saúde da Família na zona rural. Revista da Escola de Enfermagem da USP, 52, e033616. https://doi.org/10.1590/s1980-220x2017020203316

[5] Medeiros, G.C., Bergman, A. and Thuler, L.C.S. (2015) Análise dos determinantes que influenciam o tempo para o início do tratamento de mulheres com câncer de mama no Brasil. Cadernos de Saúde Pública, 31, 1269-1282. https://doi.org/10.1590/0102-311X00048514

[6] Allemani, C., Matsuda, T., Di Carlo, V., Harewood, R., Matz, M., Nikšić, M., Bonaventure, A., Valkov, M., Johnson, C.J., Estève, J., Ogunbiyi, O.J., Azevedo, E., Silva, G., Chen, W.Q., Eser, S., Engholm, G., Stiller, C.A., Monnereau, A., Woods, R.R., Visser, O., Lim, G.H., Aitken, J., Weir, H.K. and Coleman, M.P. (2018) Global Surveillance of Trends in Cancer Survival 2000-14 (CONCORD-3): Analysis of Individual Records for 37513025 Patients Diagnosed with One of 18 Cancers from 322 Population-Based Registries in 71 Countries. The Lancet, 391, 1023-1075. https://doi.org/10.1016/S0140-6736(17)33326-3

[7] Møller, H., Henson, K., Lüchtenborg, M., Broggio, J., Charman, J., Coupland, V.H., Davies, E., Jack, R.H., Sullivan, R., Vedsted, P., Horgan, K., Pearce, N. and Purushotham, A. (2016) Short-Term Breast Cancer Survival in Relation to Ethnicity, Stage, Grade and Receptor Status: National Cohort Study in England. British Journal of Cancer, 115, 1408-1415. https://doi.org/10.1038/bjc.2016.335 
[8] Ries, L.A.G., Young, J.L., Keel, G.E., Eisner, M.P., Lin, Y.D. and Horner, M.-J. (2007) SEER Survival Monograph: Cancer Survival among Adults: U.S. SEER Program, 1988-2001, Patient and Tumor Characteristics. National Cancer Institute, SEER Program, NIH. Pub. No. 07-6215, Bethesda.

https://seer.cancer.gov/archive/publications/survival/seer_survival_mono_highres.pdf

[9] Liedke, P.E., Finkelstein, D.M., Szymonifka, J., Barrios, C.H., Chavarri-Guerra, Y., Bines, J., Vasconcelos, C., Simon, S.D. and Goss, P.E. (2014) Outcomes of Breast Cancer in Brazil Related to Health Care Coverage: A Retrospective Cohort Study. Cancer Epidemiology, Biomarkers \& Prevention, 23, 126-133. https://doi.org/10.1158/1055-9965.EPI-13-0693

[10] Instituto Nacional José Alencar Gomes da Silva (INCA) (2017) Estimativa 2018: incidência de câncer no Brasil/Coordenação de Prevenção e Vigilância. Ministério da Saúde, INCA, Rio de Janeiro.

https://www.inca.gov.br/sites/ufu.sti.inca.local/files//media/document//estimativa-i ncidencia-de-cancer-no-brasil-2018.pdf

[11] Carvalho, P.L., Vilela Junior, G., Martins, G.C., Rocha, T.B.X., Mnzatto, L., Grande, A.J. and Campos, E.S. (2013) Qualidade de vida de mulheres em tratamento de câncer de mama. Journal of the Health Sciences Institute, 31, 187-192.

https://www.unip.br/presencial/comunicacao/publicacoes/ics/edicoes/2013/02_abr-j un/V31_n2_2013_p187a192.pdf

[12] Barreto, A.S.B., Mendes, M.F.M. and Thuler, L.C.S. (2012) Avaliação de uma estratégia para ampliar a adesão ao rastreamento do câncer de mama no Nordeste brasileiro. Revista Brasileira de Ginecologia e Obstetrícia, 34, 86-91. https://doi.org/10.1590/S0100-72032012000200008

[13] Dos-Santos-Silva, I., Stavola, B.L., Renna Junior, N.L., Nogueira, M.C., Aquino, E.M.L., Bustamante-Teixeira, M.T. and Silva, G.A. (2019) Ethnoracial and Social Trends in Breast Cancer Staging at Diagnosis in Brazil, 2001-14: A Case Only Analysis. The Lancet, 7, E784-E797. https://doi.org/10.1016/S2214-109X(19)30151-2

[14] World Health Organization (WHO) (2007) What Is a Gender-Based Approach to Public Health? http://www.who.int/features/qa/56/en/index.html

[15] Barbosa, R.H.S. (2001) Mulheres, Reprodução e AIDS: As tramas da ideologia na assistência à saúde de gestantes HIV+. Tese de Doutorado em Saúde Pública. Escola Nacional de Saúde Pública, Rio de Janeiro. https://www.arca.fiocruz.br/handle/icict/4547

[16] Molina, M.A.S. and Marconi, S.S. (2006) Mudanças nos relacionamentos com os amigos, cônjuge e família após o diagnóstico de câncer na mulher. Revista Brasileira de Enfermagem, 59, 514-520. https://doi.org/10.1590/S0034-71672006000400008

[17] Salvador-Pedrafita, M., Malmusi, D. and Borell, C. (2017) Time Trends in Health Inequalities Due to Care in the Context of the Spanish Dependency Law. Gaceta Sanitaria, 31, 11-17. https://doi.org/10.1016/j.gaceta.2016.06.006

[18] Uruguai (2019) Sistema Nacional de Cuidados. http://www.sistemadecuidados.gub.uy

[19] Bordo, S.R. (1997) O corpo e a reprodução da feminidade: Uma apropriação feminista de Foucault. In: Jaggar, A.M. and Bordo, S., Eds., Género, corpo, conhecimento, Record, Rio de Janeiro, 19-41.

[20] Muylaert, C.J., Sarubbi Jr., V., Gallo, P.R., Neto, M.L.R. and Reis, A.O.A. (2014) Entrevistas narrativas: Um importante recurso em pesquisa qualitativa. Revista da Escola de Enfermagem da USP, 48, 193-199. 
https://doi.org/10.1590/S0080-623420140000800027

[21] Spindola, T. and Santos, R.S. (2003) Trabalhando com a história de vida: Percalços de uma pesquisa (dora). Revista da Escola de Enfermagem da USP, 37, 119-126.

http://www.ee.usp.br/reeusp/upload/pdf/207.pdf https://doi.org/10.1590/S0080-62342003000200014

[22] Bellato, R., Araújo, L.F.S. and Castro, P. (2008) O itinerário terapêutico como uma tecnologia avaliativa da integralidade em saúde. In: Pinheiro, R., Silva Junior, A.G. and Mattos, R.A., Eds., Atenção Básica e Integralidade: Contribuições para estudos de práticas avaliativas em saúde, CEPESC, Rio de Janeiro, 169-185.

[23] Minayo, M.C.S. (1994) O desafío do conhecimento: Pesquisa qualitativa em saúde. Hucitec, São Paulo.

[24] Bardin, L. (2011) Análise de conteúdo. Edições, São Paulo, 70.

[25] Donzelot, J. (1986) A polícia das famílias. Edições Graal, São Paulo.

[26] Badinter, E. (1985) Um amor conquistado: O mito do amor materno. Nova Fronteira, Rio de Janeiro.

[27] Tronto, J. (2007) Assistência democrática e democracias assistenciais. Sociedade e Estado, 22, 285-308. https://doi.org/10.1590/S0102-69922007000200004

[28] Freire, M.M.L. (2014) A puericultura em revista. Physis, 24, 973-993. https://doi.org/10.1590/S0103-73312014000300016

[29] Jaggar, A.M. and Bordo, S.R. (1997) Gênero, corpo, conhecimento. Record, Rio de Janeiro.

[30] IPPF/WHR y Promundo (2017) Estado de la paternidad: América Latina y el Caribe 2017. IPPF/RHO, New York, Promundo-US, Washington DC.

http://www.campanapaternidad.org/wp-content/uploads/2017/06/2017-Informe-Es tado-de-la-Paternidad-LAC.pdf

[31] Scavone, L. (2005) O trabalho das mulheres pela saúde: Cuidar, curar, agir. In: Vilella, W. and Monteiro, S., Eds., Gênero e Saúde: Programa Saúde da Família em questão, ABRASCO, São Paulo, 101-111.

[32] Kergoat, D. (2009) Divisão sexual do trabalho e relações sociais de sexo. In: Hirata, H., Laborie, F., Le Doaré, H. and Senotier, D., Eds., Dicionário Crítico do Feminismo, Editora UNIFESP, São Paulo, 67-84. 